he refused the call. He appeared before two tribunals, the second of which was more sympathetic than the first and prepared to temporise. It had decided that, instead of donning military uniform he was to be allowed to work as a junior doctor at Belmont Hospital, Surrey, then an important centre for the treatment of psychiatric war casualties, both military and civil.

Belmont, as it turned out, was a godsend. Julius was intrigued by the clinical complexities of the patients' problems, and as for teachers, he had available for the asking the crème-de-lacrème of the psychiatric establishment including Louis Minski, Will Sargant, Eliot Slater and Maxwell Jones.

Julius spend 5 invaluable years at Belmont, time enough to be convinced that psychiatry must be his métier. To this end, he gained the DPM (Eng) in 1949 and the MD (Psych Med) London in 1963. He was elected FRCPsych in 1972.

He subsequently held appointments in a number of hospitals including Epsom District Hospital, St Bernard's Hospital, Southall, St Ebba's Hospital, Epsom, and St Thomas' Hospital, London. He became recognised as a Teacher in Psychiatry by the University of London. Of paramount importance, however, was the teaching he gave at the University of Surrey, in recognition of which he was elected to an Honorary Professorship. Julius was an excellent general psychiatrist, but his particular interest was in the doubtfully rewarding treatment of alcoholism and drug dependence, about which he wrote extensively and was considered a world authority.

Julius' life story would be incomplete without mentioning his sporting prowess: he was an excellent soccer player and represented London University at this game (an offer from Millwall F.C. was declined). In addition, he played a very good game of tennis. But a major preoc cupation in Julius' busy life was collecting His tastes were eclectic, with two special interests: first, he was very keen on the work of Clarice Cliff, best known as a paintress of fine china and second Victorian landscapes and Venetian scenes. The net result was that his house became a veritable Aladdin's cave, crammed from top to bottom with his accumulated treasures.

When working at Belmont, Julius met, courted and in 1953, married a Norwegian girl, Ruth Myrvang, an auxiliary nurse. They produced two children, Nina, born in 1954, and Peter in 1957. Nina is a probation officer and Peter became a consultant rheumatologist in Norwich. In 1960, the domestic bliss was shattered by Ruth's sudden illness: out of the blue, she suffered a massive subarachnoid haemorrhage. She survived, but was left severely and permanently brain-damaged with the result that she was admitted to a psychiatric hospital in Norway where she still lives. The appalling tragedy broke Julius' heart and for the rest of his life he paid regular visits to Norway to see her. The marriage was dissolved.

In 1973, Julius remarried, to Jane Forson, an occupational therapist at West Park Hospital, and they remained happily married until his death.

In 1999, Julius was diagnosed as suffering from pancreatic cancer for which he underwent a Whipple's operation with seeming success. Sadly, 3 years later, the cancer recurred: the prognosis was hopeless. At his own request, he was transferred from Epsom District Hospital to Princess Alice Hospice, where he died on 25 August 2003.

Julius remained firm to his adopted beliefs: he was cremated and the proceedings were devoid of any semblance of religious overtones and, in accordance with his prior instructions, everyone who attended the crematorium was presented with a free copy of the Socialist Standard.

Henry Rollin

Peter Merry

\section{Ian Alfred Horton}

\section{Formerly Consultant Psychiatrist, Exeter}

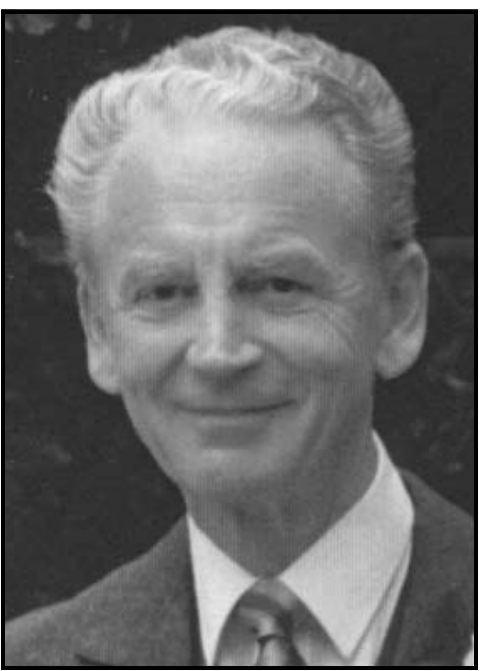

Dr lan Horton was born on 13 February 1935, and spent his childhood in Worthing, where he attended the local Grammar School and where, while roaming the South Downs he developed his affection for nature, and the countryside. He trained at St Bartholomew's Hospital, where he qualified MB.BS in 1951, and spent his 2 years' National
Service in Germany, where he acquired a love of the country and sound command of the language. He gained his MRCP(Lond) in 1956, his MRCPsych in 1971 and was elected FRCPsych in 1986.

Following his postgraduate medical experience, lan did his psychiatric training at the Maudsley Hospital, but found the aggressively challenging intellectual climate at the time, uncongenial and destructive. Resisting requests to stay, he became possibly the youngest consultant then ever appointed when he took up a post at Stone Hospital, Aylesbury. He often said he was greatly influenced by $\mathrm{Dr}$ David Watt. In 1968, he moved to Exeter, initially covering the Torbay area, where he quickly established a reputation as a thoughtful, sensitive, kind man, committed to his patients who continue to speak warmly of him whenever one meets them.

He became interested in community psychiatry, and led a group to Dingleton Hospital, Melrose, in the 1970s the leader in the field and from there he returned very enthused. The outcome was the steady establishment of community services in the Exeter district. This in turn led to the, not universally approved, early closure of two of the large psychiatric hospitals, with devolution of services to the various parts of the extensive Devon catchment area. He became the consultant to the Tiverton Community Team where he remained until the onset of the symptoms of his debilitating final illness. This forced his premature retirement, but not before the psychotherapy service, which he had so actively promoted, was set up.

Although well-trained in general medicine, lan was a 'natural' psychiatrist, interested in people, the mind, spirituality and society. He thought a lot, he tended to agonise and is remembered as saying 'I do wish I could be a better person'. He was brought up as a Methodist, but moved to the Anglican Church only to find that equally unsatisfying. Ultimately, he joined the Quakers, which seemed to suit his temperament admirably and with which we will join in a meeting of remembrance.

He loved music, playing the clarinet, literature, nature, walking, travelling and good conversation: it was particularly distressing that his illness, which he bore with courage and dignity, robbed him progressively of the ability to communicate. lan played an important part in the first phase of the modernisation of the Devon psychiatric services and he will be remembered for this, as well as his kindness to both colleagues and patients, all of whom will greatly miss him. He died on 8 October 2003, and leaves his second wife Annie, four children by his first wife Brenda, and seven grandchildren.

\section{G. D. P. Wallen}

